\title{
Isoetes maxima, a New Species from Brazil
}

Author(s): R. James Hickey , C. Cecilia Macluf, and Melanie Link-Pérez

Source: American Fern Journal, 99(3):194-199. 2009.

Published By: The American Fern Society

DOI: http://dx.doi.org/10.1640/0002-8444-99.3.194

URL: http://www.bioone.org/doi/full/10.1640/0002-8444-99.3.194

BioOne (www.bioone.org) is a nonprofit, online aggregation of core research in the biological, ecological, and environmental sciences. BioOne provides a sustainable online platform for over 170 journals and books published by nonprofit societies, associations, museums, institutions, and presses.

Your use of this PDF, the BioOne Web site, and all posted and associated content indicates your acceptance of BioOne's Terms of Use, available at www.bioone.org/ page/terms_of_use.

Usage of BioOne content is strictly limited to personal, educational, and noncommercial use. Commercial inquiries or rights and permissions requests should be directed to the individual publisher as copyright holder. 


\title{
Isoetes maxima, a New Species from Brazil
}

\author{
R. JAMES HiCKEY \\ Botany Department, Miami University, Oxford, Ohio 45056 USA \\ C. Cecilia Macluf \\ Cátedra de Palinología, Facultad de Ciencias Naturales y Museo, Universidad Nacional de La Plata, \\ Paseo del Bosque s/n, 1900 La Plata, Argentina \\ MELANIE LiNK-PÉREZ \\ Botany Department, Miami University, Oxford, Ohio 45056 USA
}

\begin{abstract}
Aвstract.-Isoetes maxima from eastern Brazil is described as a new species. This taxon differs from other fully aquatic species in South America by a combination of its overall size, leaf coloration, finely tapering subulae, and megaspore morphology.
\end{abstract}

KeY Words.-Isoetes maxima, Brazil, new species

While examining Isoetes from eastern Brazil, we encountered a specimen whose large size and dark coloration are unlike any known species from that region. The plants have numerous, very narrow, densely packed, and finely tapering leaves, and its megaspores are rugulate to tuberculate. In contrast, other large Isoetes in this region of South America have broader leaves that are less densely packed, and reticulate megaspores (Fuchs-Eckert, 1986; Macluf et al., 2008).

The specimens in question were collected by Aloysio Sehnem in 1970. Sehnem determined his collection to be a new species and designated it so on the label as Isoetes maxima. The label indicates the collection as the intended holotype; however, Sehnem never described or validly published the new species. We have elected to use the name that Sehnem had inscribed on the specimen label since the overall stature and robust appearance of the taxon merit the appellation.

Isoetes maxima Hickey, Macluf and Link-Pérez, sp. nov. TYPE.-BRAZIL. Cambará, Fortaleza, Aparados, in aqua rivi in campo, $1200 \mathrm{~m}, 2 / 5 / 70, A$. Sehnem 10960 (PACA 74904). (holotype: PACA; isotypes: FHS). Figs, 1-14.

Cormus erectus, bilobatus, $2.5-3.0 \mathrm{~cm}$ latus; radices succulentae, dichotomae. Foliae 30-50, ad $45 \mathrm{~cm}$ longae, strictae, erectae, 1.5-2.0 $\mathrm{mm}$ latae ad medium, ca 8-10 $\mathrm{mm}$ latae basi; alae atrovirentes vel fuliginosae, $2.0 \mathrm{~mm}$ latae ad sporangium, 10-25 cm longae (20-50\% per foliae longitudinem ascendentes), apice attenuato; subula atrovirens, erecta, semi-teres, apice longiattenuato, neque nitido neque corneo; fasiculi fibrosi peripherici praesentes; squamellulis carentibus. Labium triangule, 850-875 $\mu \mathrm{m}$ altum, 475-500 $\mu \mathrm{m}$ latum. Ligula magna, auriculata manifeste; pulvinus residuus triangularis, persistens, ca $2 \mathrm{~cm}$ longum et $1.5 \mathrm{~mm}$ latum. Velum incompletum, 30-50\% 


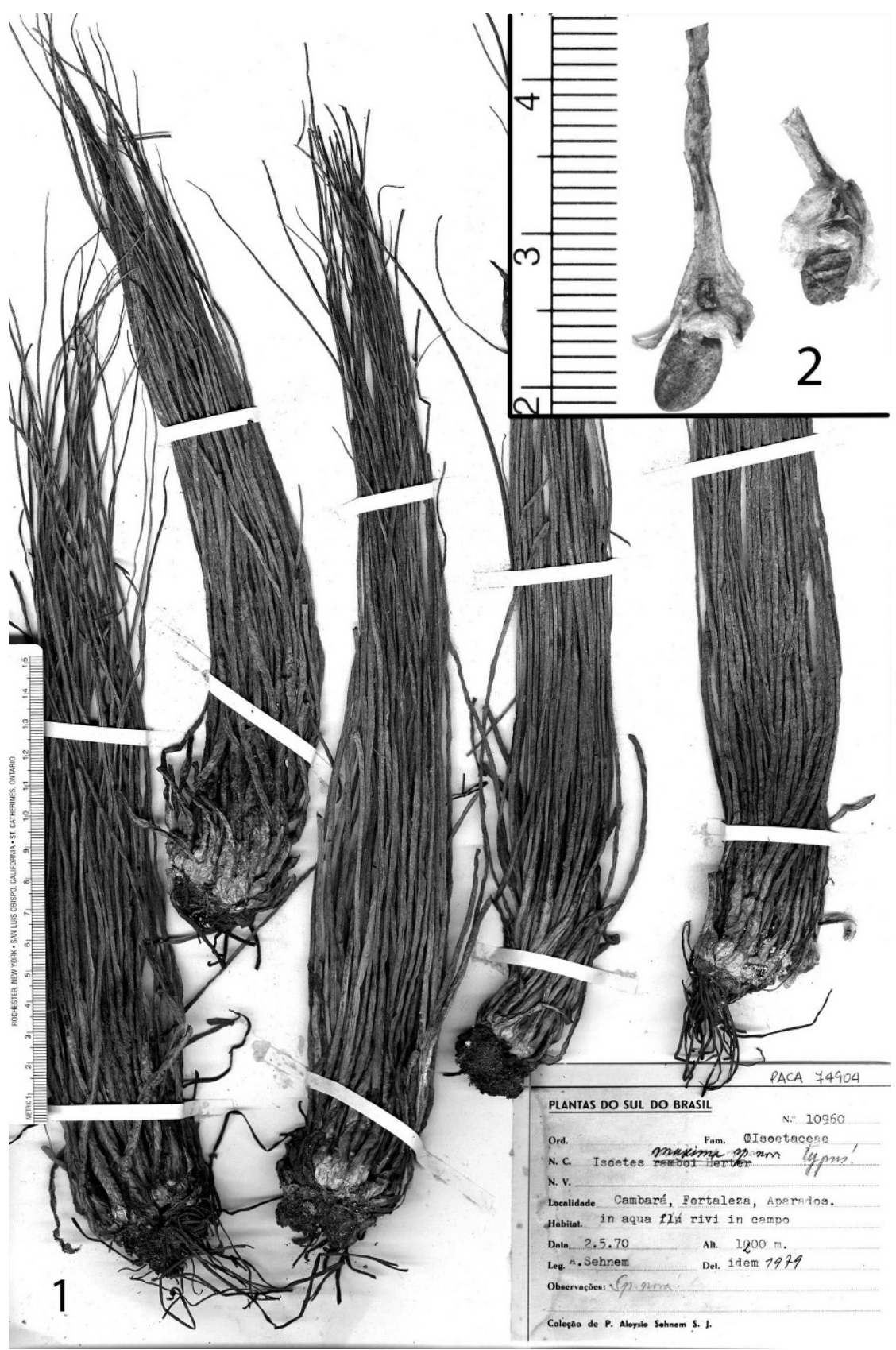

Figs. 1-2. Holotype of Isoetes maxima (Sehnem 10960, PACA). 1. Whole plant. 2. Adaxial views of two sporophylls with microsporangia, partial velum and ligule fragments. 


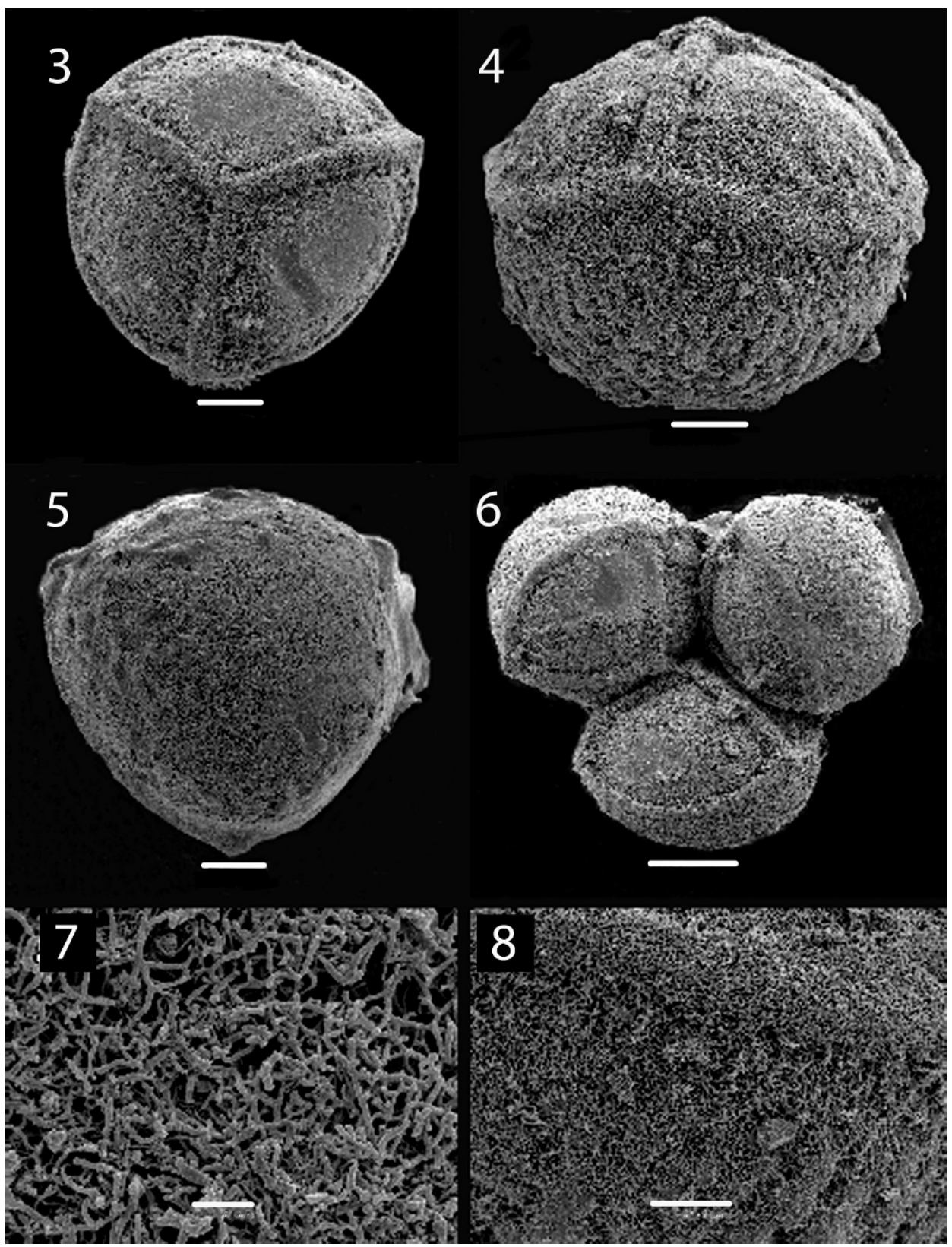

FIGS. 3-8. Scanning electron micrographs of Isoetes maxima megaspores (Sehnem 10960, PACA). 3. Proximal view of a megaspore. 4. Equatorial view of a megaspore. 5. Distal view of a megaspore. 6. Three of the four spores of a single tetrad. 7. High magnification of the distal surface. 8. Detail of the equatorial zone, with both the equatorial ridge and a weak girdle visible. Fused tubercles, rugae, are visible in Figs. 4, 5 and 8. Scale bar $=100 \mu \mathrm{m}$ in Figs. 3-5; $200 \mu \mathrm{m}$ in Fig. 6; $\mu \mathrm{m}$ in Figs. 7 and 8. 


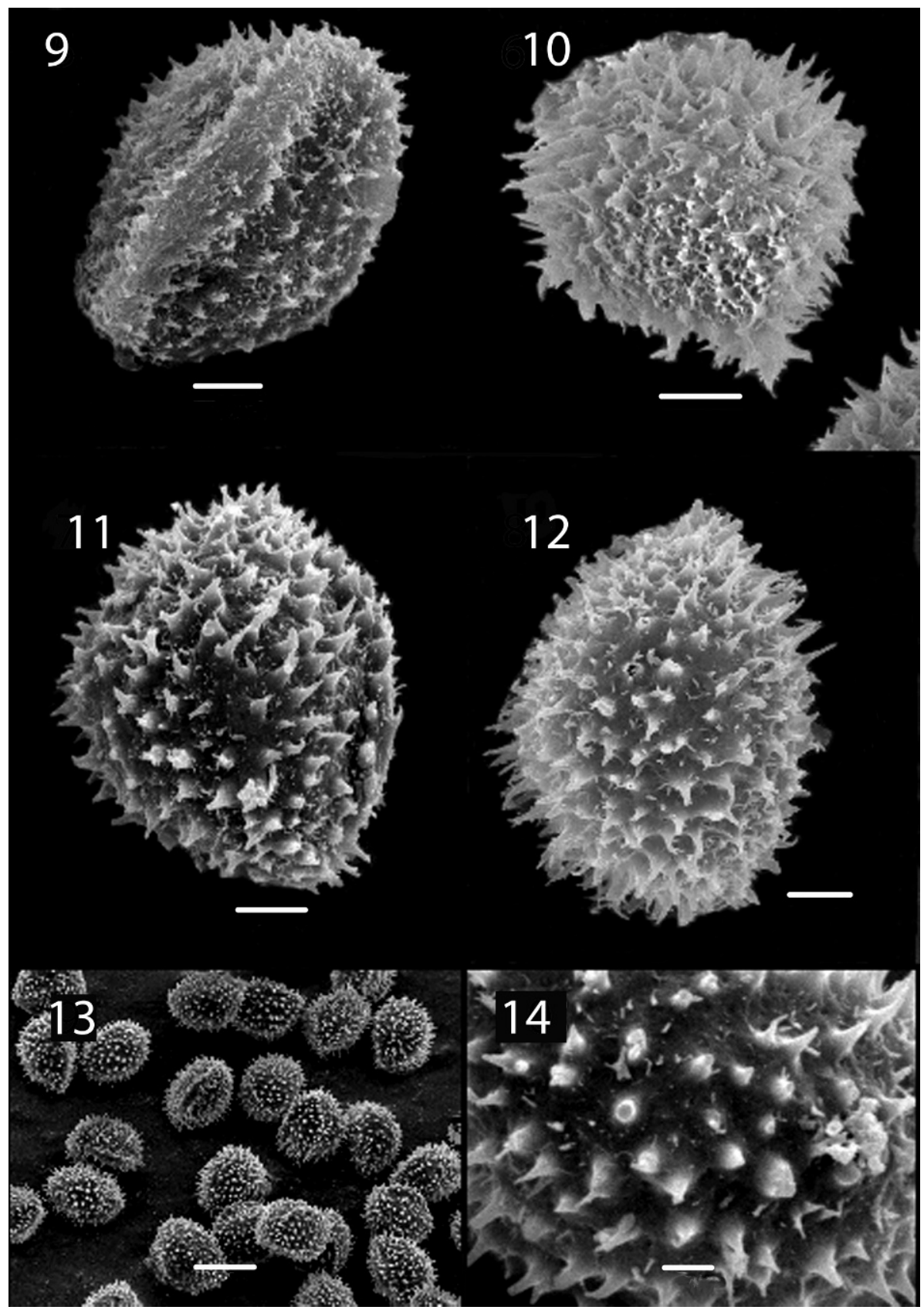

FIGs. 9-14. Scanning electron micrographs of Isoetes maxima microspores (Sehnem 10960, PACA). 9. Proximal view. 10. Equatorial view showing the supra-laesural expansion. 11. Equatorial view. 12. Distal view. 13. Several microspores in different views. 14. High magnification of the distal echinate ornamentation. Scale bar $=5 \mu \mathrm{m}$ in Figs. 9-12, $20 \mu \mathrm{m}$ in Fig. 13, and $2.5 \mu \mathrm{m}$ in Fig. 14. 
per sporangium longitudinem descendens. Sporangium basale, ellipticum, hyalinum, 5-6 mm longum, 2-4 mm latum, non maculatum. Megasporae cretaceae, triletae, 525-(583.8)-650 $\mu \mathrm{m}$ diametro, globosae, pagina distalis verrucata vel tuberculata (vel laevis), pagina proximalis laevis, cingulum leave. Microsporae brunneae vel atrobrunneae, monoletae, 27-33 $\mu \mathrm{m}$ longae, 20-23 $\mu \mathrm{m}$ latae, echinatae.

Plants large, corms erect, bilobed, 2.5-3.0 cm across. Roots numerous, succulent, dichotomously branched. Leaves $30-50$, to $45 \mathrm{~cm}$ long, straight, erect, 1.5-2.0 mm wide at mid-length, ca 8-10 $\mathrm{mm}$ wide at the base; alae dark green to brown, $2.0 \mathrm{~mm}$ wide at the sporangium, extending $10-25 \mathrm{~cm}$ up the leaf (20-50\% of total leaf length), apex attenuate; subula dark green, erect, appearing half-terete, apex long attenuate, neither glossy nor corneous, fibrous bundles present; scales absent. Labium triangular, 850-875 $\mu \mathrm{m}$ high, 475$500 \mu \mathrm{m}$ wide. Ligule large, massive, distinctly auriculate; cushion dark, persistent, triangular, ca $2 \mathrm{~mm}$ long, $1.5 \mathrm{~mm}$ wide. Velum extending down and covering $30-50 \%$ of the sporangium; lower velum also present and covering $5-$ $10 \%$ of sporangium. Sporangium basal, elliptic, hyaline, 5-6 mm long, 2$4 \mathrm{~mm}$ wide, concolorous. Megaspores dull white, trilete, 525-(583.8)-650 $\mu \mathrm{m}$ in equatorial diameter, distal surface rugulate to tuberculate (to laevigate), comprised of an open reticulum of fibrils, proximal surfaces laevigate, subtriangular to globose in polar view and globose in equatorial view, laesurae $44.5 \mu \mathrm{m}$ high, equatorial ridge $30 \mu \mathrm{m}$ wide, girdle typically smoother than the distal ornamentation. Microspores brown to dark brown en masse, monolete, 27-33 $\mu \mathrm{m}$ long, 20-23 $\mu \mathrm{m}$ wide, elliptic in polar view, proximal face convex and distal face broadly rounded, perispore surface echinate with longer echinae distally.

PARATYPES.-BRAZIL. Itaimbezinho, Sao Francisco do Paulo, in stagno ad flumen Perdizes, alt. 900 m, Dec. 24, 1980, A. Sehnem 17148 (PACA 74905). Cambará, Fortaleza, in rivulo submersum in lectu, alt. 1000m, Jan 10, 1973. A. Sehnem 12362 (PACA 74906).

Isoetes maxima is an aquatic endemic known only from three collections out of the Cambará region of Rio Grande do Sul in Brazil. It grows submerged in streams at elevations of 900 to $1200 \mathrm{~m}$.

Species of Isoetes from Rio Grande do Sul have either reticulate or tuberculate-rugulate to rugulate megaspores. The reticulate-spored species of South America are in desperate need of revision. Those species of eastern and southern South America (from Minas Gerais to Buenos Aires) constitute an exceptionally difficult assemblage, having had less attention paid to them than the reticulate-spored species of the northern Andes. Fuchs-Eckert (1986) treated the reticulate-spored species of this region, focusing primarily on the State of Santa Catarina. Although most non-Andean reticulate species were covered, these taxa are still imperfectly differentiated.

The only two non-reticulate species in southeastern Brazil are Isoetes weberi Weber and Isoetes maxima. Megaspore ornamentation in both species varies from tuberculate to rugulate, but the species differ dramatically in megaspore 
size: Isoetes weberi spores have a mean of $356 \mu \mathrm{m}$ and a range of 220 to $450 \mu \mathrm{m}$; those of I. maxima range from 525 to $650 \mu \mathrm{m}$ with a mean of $583 \mu \mathrm{m}$. At high magnifications, the megaspore surfaces of both species consist of a coarse open reticulum of structural elements. This type of surface is not seen in any of the reticulate spored species. Microspores in both species are fundamentally echinate, but in $I$. weberi the echinae are broader, more columnar and distally muricate (Hickey, 1985). Both species have moderately well developed vela extending about $50 \%$ down the sporangium. The species also differ markedly in the size and shape of the labium. In I. maxima the labium is narrowly triangular, with a length to width ratio of about 1.8 to 1 and reaching lengths of $0.85-0.88 \mathrm{~mm}$ in height. The labium of $I$. weberi ranges from 1.0-1.8 $\mathrm{mm}$ in height, is narrowly oblong and has a length to width ratio of 2.3-3.3. The labium of $I$. weberi is typically bifid distally, a condition otherwise known only in I. tennesseensis Luebke and Budke (Budke et al., 2005).

Isoetes weberi is a lowland species growing at elevations of $10-20 \mathrm{~m}$ whereas I. maxima is found at about $1200 \mathrm{~m}$. The presence of scale leaves around the corms in $I$. weberi suggests that it frequents drier habitats with only seasonal inundation, and so differs from the more aquatic Isoetes maxima.

The rather large megaspores seen in Isoetes maxima suggest an origin through polyploidy. Within the vicinity of I. maxima only I. weberi stands as a likely parent. In fact, the similar morphology and habit in conjunction with the common, open reticulum of the megaspores suggest an affinity between these two. Candidates for a second parent are more problematic and perhaps must be sought further north in the states of Bahia, Espirito Santo and Rio de Janeiro, perhaps to the poorly understood I. organensis Weber or I. ulei Weber.

\section{Literature CiteD}

Budke, J. M., R. J. Hickey and K. D. Heafner. 2005. Analysis of morphological and anatomical characteristics of Isoetes using Isoetes tennesseensis. Brittonia 57:167-182.

Fuchs-Eckert, H. P. 1986. Isoetáceas. Pp. 3-43 in R. Reitz, ed. Flora Ilustrada Catarinense, I Parte Fascículo. Itajaí, Santa Catarina, Brasil.

Hickey, R. J. 1985. Revisionary Studies of Neotropical Isoetes. Ph.D. Dissertation, Univ. of Connecticut, Storrs, CT.

Macluf, C. C., M. A. Morbelli and G. E. Giudice. 2008. Megaspore morphology of Isoetes species (Lycophyta) from southern Brazil. XII Simpósio Brasilero de Paleobotánica y Palinología (Florianópolis, Brasil, Noviembre de 2008), Boletim de Resumos, p. 129. 